Journal of Research in Technical Careers December 2019, Vol. 3, No. 2.

(C) Author(s)

\title{
Building a Sustainable Agricultural Career Pipeline: Effective Recruitment and Retention Practices Used by Colleges of Agriculture in the United States
}

\author{
Antoine J. Alston ${ }^{\mathrm{a}}$, Richie Roberts ${ }^{\mathrm{b}}$, Chastity Warren English ${ }^{\mathrm{a}}$ \\ ${ }^{a}$ North Carolina A\&T State University, ${ }^{b}$ Louisiana State University
}

\begin{abstract}
This national study examined effective student recruitment and retention practices used by colleges of agriculture in the United States among 1862 land-grant, 1890 land-grant, and non-land-grant institutions. Respondents reported that faculty at colleges of agriculture were primarily white. Through the analysis of sub-group percentages, the researchers found that the ethnic makeup of faculty was not reflective of the general population. The researchers found that administrators from 1862 land-grant institutions reported statistically significant differences $(\mathrm{p}<.05)$ regarding the use of specific strategies to target underrepresented populations in student recruitment as compared to other institutional types. Further, 1862 land-grant institutions reported statistically significant differences in student retention strategies $(p<.05)$ as compared to other institutional types regarding the delivery of programs that aimed to retain first-year students. Based on key findings from this investigation, the authors developed the agricultural student retention model (ASRM) to help guide colleges of agriculture in improving their holistic retention program as they navigate inclusive and diverse institutional contexts. Additionally, key recruitment strategies were identified as well, that could facilitate holistic student recruitment efforts. Perhaps more significant progress can be made toward creating a sustainable agricultural workforce that is more reflective of U.S. population demographics using this model.
\end{abstract}

Keywords: agricultural students, recruitment, retention model, workforce development

\section{Introduction}

Institutions of higher education are under mounting scrutiny as they face reduced student access, rising costs, and calls to demonstrate more profound outcomes (Beale, 2012; Kretovics, 2011). As a result, trends regarding student entrance, retention, and graduation as key indicators of institutional successes and failures are being highlighted (Adams-Johnson, Cranmore, Holloway, \& Wiley, 2019). Although existing evidence has revealed that such metrics are affected by a number of contextual factors (Allen, Robbins, Casillas, \& Oh, 2008; Shrestha, Suvedi, \& Foster, 2011), they remain of central importance 
to universities because student dropout results in fewer individuals prepared to enter the workforce as well as thousands of dollars in unrealized revenue for institutions (Beale, 2012; Kretovics, 2011). Also, not completing a college degree has been shown to negatively affect leavers' social, physiological, and economic wellbeing (Bruffaerts et al., 2018; Pervin, Reik, \& Dalrymple, 2015). For example, previous research has reported statistically significant relationships between individuals who drop out of college and their sense of social isolation and depression as well as a lower career earning potential (Bruffaerts et al., 2018; Pervin et al., 2015). Moreover, with national student loan debt topping \$1.5 trillion in 2019, and students graduating in 2017 having an average of \$28,650 in loans, the success of universities and students remain deeply entwined (Friedman, 2019).

To further complicate this issue, nearly all agricultural, food, and natural resource (AFNR) sectors are experiencing a shortage of qualified workers (Goecker, Smith, Marcos Fernandez, Ali, \& Goetz, 2015). For instance, it is expected that more than 20,000 AFNR related jobs will go unfilled annually by 2020, with employers having trouble finding qualified individuals for these positions (Goecker et al., 2015). Therefore, it is imperative to improve the recruitment and retention of colleges of agriculture to ensure that qualified leaders supply the AFNR career pipeline in the future (National Research Council, 2009; STEM Food and Agriculture Council, 2014). Previous research on this issue, however, has depicted the rift between the supply and demand of AFNR graduates as an issue of student recruitment (Baker, Settle, Chiarelli, \& Irani, 2013; Koon, Frick, \& Igo, 2009; Rayfield, Murphrey, \& Skaggs, 2013; Rocca \& Washburn, 2005; Stair, Danjean, Blackburn, \& Bunch, 2016). However, less attention is placed on the role that retention plays in solving this problem (Dunn, Haines, \& Epps, 2013). In response, Koon et al. (2009) called for colleges of agriculture to consider recruitment and retention as factors of equal value. As an illustration, by placing an improved emphasis on retention efforts, colleges of agriculture could better address the national student loan debt by graduating students promptly while also keeping more individuals in the AFNR career pipeline (Koon et al., 2009).

Previous research has demonstrated that targeted university recruitment and retention programming can positively influence individuals' choice to pursue college as well as their decision to persist throughout their degree program (Bobbit, 2006; Herren, 2005; Rocca, 2013). In particular, the literature on recruitment for colleges of agriculture has reported that communicating and building relationships with parents is critical because they are highly influential in their child's decision to pursue a career in agriculture as well as the particular university they ultimately choose to attend (Bobbit, 2006; Herren, 2005; Rayfield et al., 2013; Rocca, 2013; Dyer, Breja, \& Wittler, 2002). However, variables such as campus visits, cost, communication efforts from colleges and departments, departmental atmosphere, experiential learning opportunities, faculty approachability, and scholarship opportunities have also been reported to influence agriculture students' decisions (Baker et al., 2013; Herren, 2005; Rayfield et al., 2013; Rocca \& Washburn, 2005; Stair et al., 2016).

Despite this progress, evidence of effective retention practices remains tentative (Dunn et al., 2009). For example, Dunn et al. reported mixed results regarding students' perspectives of the University of Kentucky's retention efforts. Specifically, students 
perceived they had positive relationships with faculty and their peers through their coursework and extracurricular activities; however, they did not sense a full integration into the academic community and desired to establish a stronger connection with the institution (Dunn et al., 2009). Therefore, more effort is needed to understand how effective recruitment and retention practices are used in tandem by colleges of agriculture to strengthen the AFNR career pipeline, especially as such institutions become more diverse in the future. If colleges of agriculture begin to place more emphasis on the retention of students, it could yield several other positive multiplier effects as well. For example, the retention rates of universities are often considered indicators of quality in key performance areas such as accreditation, alumni and donor support, institutional rankings, as well as federal funding opportunities (Thammasiri, Delen, Meesad, \& Kasap, 2013). Further, this move could improve relationships between universities and the communities they serve since enhanced graduation rates have been reported to improve local tax earnings (Day \& Newburger, 2002), students’ sense of civic responsibility (Bradburn, Nevill, \& Cataldi, 2006), and the public's perception of higher education (Cantor, 2004).

So far, the literature on retention in agriculture has primarily focused on using students' grade point average (GPA) and American College Testing (ACT) score to predict students' success (Garton, Dyer, \& King, 2001; Johnson, Shoulders, Edgar, \& Dixon, 2018). For example, Johnson et al. (2018) reported that "every one-point increase in high school grade point average was associated with a $245 \%$ increase in the likelihood of being retained in an agricultural-related major (p. 218)". Despite this insight, however, retention continues to be difficult for colleges of agriculture to address. One explanation for this challenge is that multifaceted contextual influences often moderate retention rates at the student, institutional, and environmental levels (Mattern et al., 2015). As such, colleges of agriculture must carefully consider whether a particular retention practice complements the unique social, cultural, and community-based context (Garton et al., 2001). A need emerged, therefore, to better understand effective recruitment and retention practices used by colleges of agriculture. In the future, such insights could help align appropriate intervention techniques with at-risk populations while also better supporting students as they enter and progress through the AFNR career pipeline.

\section{Theoretical Framework}

The theoretical framework of this study is based upon Chapman's (1981) Model of Influences on Students' College Choice, and Astin’s (1985) Student Involvement Theory.

Model of Influences on Students' College Choice. Chapman's (1981) model provides a framework to understand how students make decisions regarding their choice to pursue higher education (Figure 1). As such, this model suggests that a combination of student characteristics and external factors influences students' college choices. Specifically, the external influences were grouped into three general categories: (1) the importance of significant persons, (2) the fixed characteristics of the institution, and (3) the institution's efforts to communicate with prospective students. Through the lens of Chapman's model, student characteristics are also categorized into the following 


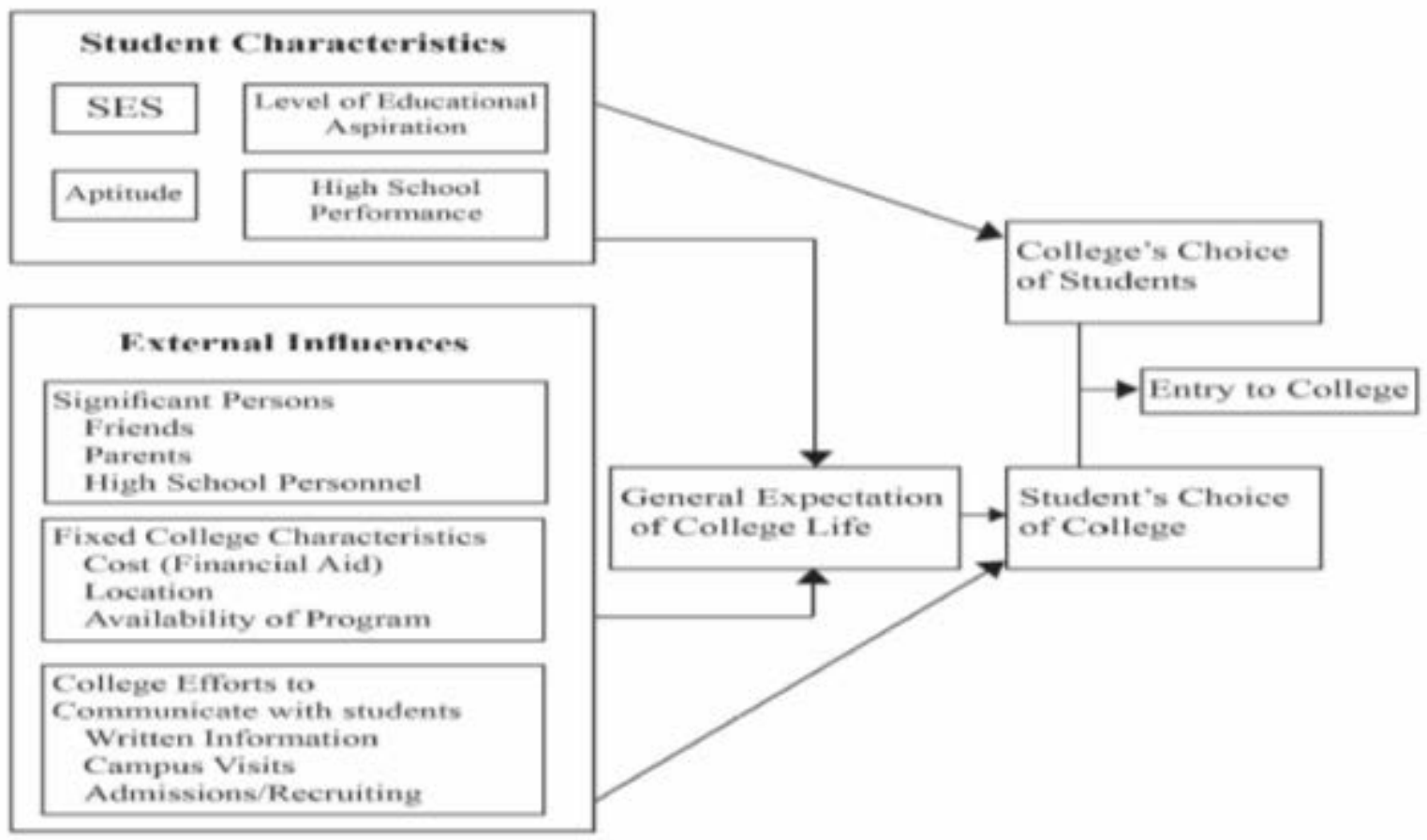

Figure 1. Model of Influences on Student College Choice (Chapman, 1981).

categories: (a) socioeconomic status, (b) high school performance, (c) aptitude, and (d) level of educational aspiration. Overall, the model is considered longitudinal and suggests that it is imperative to account for students' characteristics, features of the college, and the influence of a students' family. Such factors directly impact higher education in the context of agriculture as well. For instance, the model provides insight into how a student might select an agricultural major and the university in general.

Astin's Student Involvement Theory. Astin's (1985) Theory of Student Involvement is a framework that describes how desirable outcomes of colleges are understood concerning the changes that students experience over time as well as how they mature as a result of co-curricular activities. The theory is conceptualized using three components (Figure 2). The first component involves a student's inputs, which encompasses factors such as their background, previous experiences, and demographics. The next element is the student's environment, which is comprised of all the skills a student would encounter during their collegiate studies. The last part reflects outputs such as the student's knowledge, beliefs, personal characteristics, attitudes, and values that exist after they have enrolled through their degree program.

Regarding student retention, Astin (1985) advanced five underlying assumptions. First, student involvement is an investment of psychosocial and physical energy over time. Next, a student's participation is continuous, and the overall energy invested fluctuates 


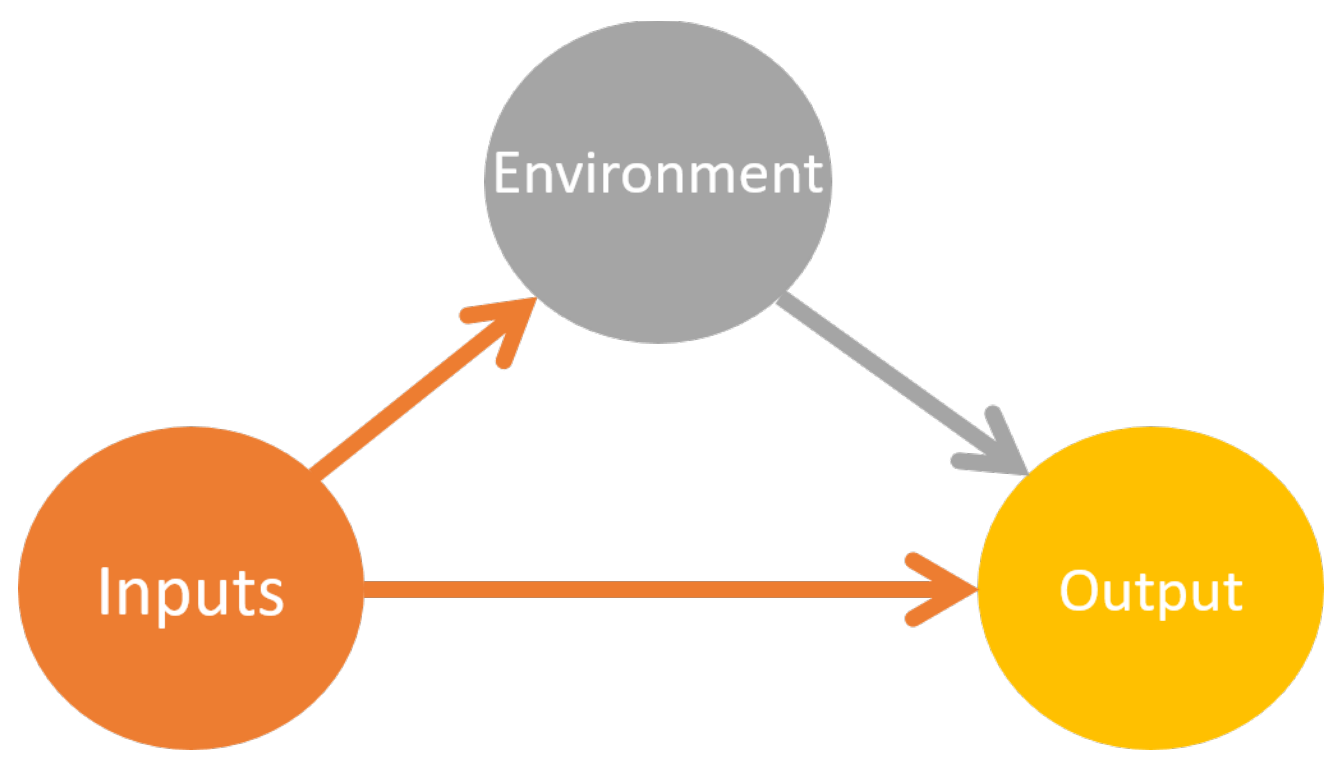

Figure 2. Astin’s Student Involvement Theory (1984)

depending on the individual. The third component may be qualitative or quantitative but represents the changes that students undergo as they grow intellectually. The fourth component suggests that a student's outputs are directly connected to their commitment to their development. The last part indicated that a student's academic performance is directly related to the student's effort and involvement. Overall, therefore, this theory has many applications in higher education, but particularly for student retention since it provides theoretical guidance for how co-curricular student engagement can influence students learning and progression, i.e., success in their degree program. Therefore, both theories were pivotal to understanding how students entered and successfully moved through their agricultural-related degree programs.

\section{Purpose}

Using the two theoretical lenses, the purpose of this investigation was to describe effective student recruitment and retention practices by colleges of agriculture in the United States at land-grant and non-land-grant institutions.

\section{Objectives}

The following objectives were developed to guide this study:

1. Describe the demographic characteristics of colleges of agriculture. 
Journal of Research in Technical Careers

2. Describe the recruitment strategies currently utilized to attract students into agricultural science-based majors at land-grant universities and non-land-grant universities.

3. Describe the recruitment strategies currently utilized to attract underrepresented students into agricultural science-based majors at land-grant universities and nonland-grant universities.

4. Describe student retention strategies currently utilized by agricultural academic units at land-grant universities and non-land-grant universities.

5. Describe student retention strategies currently utilized by agricultural academic units at land-grant and non-land-grant universities for underrepresented students.

6. Examine differences in agricultural institution type and diversity office presence with regards to the administrators' decisions to utilize specific recruitment and retention strategies.

- $\mathrm{H}_{\mathrm{o}}$ : No differences exist among agricultural institution type concerning their decision to utilize specific student recruitment strategies.

- $\mathrm{H}_{0}$ : No differences exist among agricultural institution type concerning their decision to utilize specific student retention strategies.

- $\mathrm{H}_{\mathrm{o}}$ : No differences exist among agricultural institutions with college diversity and inclusion offices versus those that do not have diversity and inclusion offices concerning their decision to utilize specific student retention strategies.

\section{Method}

Before this study, no national studies had been conducted upon land-grant and nonland-grant colleges of agriculture collectively, to gauge the specific strategies utilized for student recruitment and retention. Therefore, in this study, the researchers designed a webbased instrument to accomplish the objectives of this study. The questionnaire was developed after a thorough review of the literature concerning best practices in higher education regarding recruitment and retention, using reports distributed by Ruffalo Noel Levitz (2015, 2017). The questionnaire consisted of the following three sections: Section I: Recruitment Practices, 19 items, Section II: Retention Practices, 21 items, and Section III: Agricultural College Demographics, five items. Sections one and two used the following Likert scale: 1 = Never, 2 = Rarely, $3=$ Sometimes, $4=$ Often, and $5=$ Always. Within these respective sections, the item structure was designed to have respondents indicate to what extent each practice was used for all students and underrepresented populations. It is also important to note that the data reported in this manuscript are part of a larger investigation that examined student retention from a student, faculty, and administrative perspective. However, only data regarding the administrator's perspective have been reported here.

For this study, the web-based instrument was distributed to all college of agriculture academic administrators throughout the United States, as listed with the Association of Public and Land-grant Universities (APLU) for the 2016-2017 academic year. A threeround, web-based survey design approach was utilized for this study, which resulted in 58 
completed surveys out of 124 (47\% return rate). Of note, Dillman, Smyth, and Christian's (2014) tailored design method was used to achieve an optimal return rate, given its extensive usage in social science research and proven methodology.

The validity of the instrument was established through content and face validity. Brown (1983) defined content validity as "the degree to which items on a test representatively sample the underlying content domain” (p. 487). Brown (1983) recommended using expert judges as a way to establish content and face validity. The panel of experts consisted of the college of agricultural administrators $(n=20)$ who were not included in this study, primarily department chairs, from select APLU institutions. The panel of experts determined the instrument to be valid after a thorough review process.

A pilot test was conducted with a panel of experts. Reliability assures the dependability or precision of an instrument. Cronbach's alpha was used as the reliability measure for this study. One of the benefits of Cronbach's alpha is that it provides insight into the items that best measure a phenomenon. Nunnally (1967), Nunnally (1978), and Schmidt and Hunter (1996) suggested that significance values of $p<0.5$ to $p<0.6$ are acceptable in the early stages of research. Further, Nunnally (1978) indicated that in contrast to the standards of basic research, in many applied settings reliability of 0.80 might not be high enough, but it depends on how the measure is used and what is considered satisfactory for that field. Measurements of 0.90 might not be high enough where precision is needed. In this study, therefore, it was determined that measures of at least 0.85 were considered satisfactory, after a review of literature in some other areas of social science research (Schmidt \& Hunter, 1996). Cronbach's alpha reliability coefficients for the instrument were as follows: Section One $=0.87$, Section Two $=0.85$. As such, no adjustments were made to the instrument after reliability analysis. Given the size of the population, researchers deemed this response rate acceptable (Fan \& Yan, 2010; Lance, Butts, \& Michels, 2006). To control for non-response error, Miller and Smith (1983), Lindner and Wingenbach, (2002), and Lindner, Murphy, and Briers (2001) recommended comparing early to late respondents. Research has shown that late respondents are often similar to non-respondents. For this study, early respondents were defined as individuals who completed the questionnaire within the first week of distribution, and late respondents were defined as any responses received after the first week. No statistically significant differences $(p>.05)$ were found between early and late respondents in this study.

Data Analysis. For this investigation, we used a range of descriptive and statistical analysis procedures to address the research objectives. Specifically, we used descriptive statistics such as (a) frequencies, (b) percentages, (c) means, and (d) standard deviations. Then, we used ANOVA's and independent samples t-tests to analyze differences regarding student recruitment and retention practices to the specific college of agriculture demographic characteristics. Finally, effect sizes for tests of mean differences were reported using Cohen's $d$ (Field, 2013). 


\section{Findings}

Demographics. Objective one sought to describe the demographic characteristics of colleges of agriculture in the United States. In regard to institution type, 50\% $(f=29)$ identified as 1862 land-grant institutions, non-land-grant institutions represented 36\% ( $f=$ 21) of respondents, and 1890 land-grant institutions represented $14 \%(f=8)$ of respondents. As for geographic location, 29\% ( $f=17)$ of the reporting institutions were located in the Southeast, followed by Midwest with 22\% ( $f=21)$, the Northeast and Southwest with $19 \%$ ( $f=11$ ), and the Northwest with $10 \%(f=6)$. Concerning student enrollment and race/ethnicity, the reporting institutions on average had 66\% White, 14\% Black, 7\% Hispanic, 6\% Asian, and 5\% Native American and others. Another demographic variable considered was faculty race/ethnicity. The reporting institutions had on average of $71 \%$ White faculty, followed by Black and Asian with 9\% each, Hispanic 3\%, other 9\%, and Native American $0.86 \%$. Finally, respondents were asked to reveal whether their institution had a diversity office in their respective college, with $40 \%(f=23)$ indicating they did have an office of diversity compared to $60 \%(f=35)$ that did not.

Student Recruitment Strategies. For objectives two and three, the goal was to describe the specific student recruitment strategies utilized by colleges of agriculture for all students as well as underrepresented students. Table 1 provides a summary of the relevant findings. Specifically, the highest-rated student recruitment strategies were: (a) email communication, (b) a website optimized for mobile browsers, (c) campus open house events, (d) campus visit days for high school students, (e) targeting in-state students, (f) social media, and (g) a sequential flow of communication during the entire recruiting cycle. The strategies as mentioned above were rated high in both the all students category and underrepresented students category. In contrast, the six lowest-rated items included: (1) online college fairs, (2) overnight visits for high school students, (3) call cell phones, (4) targeting part-time students, (5) meetings for events for high school counselors, and (6) asking current students/alumni for applicant referrals.

Student Retention Strategies. For objectives four and five, the goal was to describe specific student retention strategies utilized by colleges of agriculture for students as well as underrepresented students. The highest-rated student retention strategies for both all and underrepresented students were: (a) academic support, (b) giving students practical work experiences in their intended major, (c) advising by professional staff, one-on-one, (d) programs explicitly designed for first-year students, (e) mandatory first-year experience or orientation course, (f) providing each student with an academic plan/roadmap of classes, (g) mandatory advising by professional staff, one-on-one, (h) early-alert and intervention system for campus-based learners, and (i) faculty development and support in online technology and online teaching pedagogy. In comparison, the lowest-rated retention strategies used with both groups of students were: (a) programs explicitly designed for second-year students, (b) programs for part-time students, (c) programs designed specifically for adult/non-traditional students, and (d) mandatory academic advising for online learning. Table 2 provides an overview of these findings for objectives four and five. 
Table 1. Agricultural Student Recruitment Strategy Comparison

\begin{tabular}{|c|c|c|c|c|}
\hline Recruitment Practices & $\begin{array}{l}\text { All Students } \\
\qquad M\end{array}$ & SD & $\begin{array}{l}\text { Underrepresented } \\
\text { Students } \\
M\end{array}$ & SD \\
\hline Text Messaging. & 2.14 & .974 & 2.10 & .942 \\
\hline Email Communication. & 4.12 & 1.23 & 4.09 & 1.13 \\
\hline Website optimized for Mobile Browsers. & 4.19 & .742 & 4.19 & .757 \\
\hline Campus Open House Events. & 4.45 & 1.32 & 4.31 & 1.22 \\
\hline Campus Visit Days for High School Students. & 4.12 & .874 & 4.22 & .806 \\
\hline Weekend Visit Days. & 3.05 & 1.13 & 3.03 & 1.21 \\
\hline $\begin{array}{l}\text { Booths at State and National FFA and 4-H } \\
\text { Conventions. }\end{array}$ & 4.03 & .823 & 3.95 & .861 \\
\hline $\begin{array}{l}\text { Campus Recruiter Visits to High School } \\
\text { Agricultural Education Programs. }\end{array}$ & 3.64 & 1.34 & 3.60 & 1.26 \\
\hline Targeting in-state students. & 4.12 & 1.04 & 4.19 & 1.17 \\
\hline Social Media (Facebook, Instagram, Twitter). & 3.98 & .326 & 3.97 & 413 \\
\hline Meetings for Events for High School Counselors. & 2.95 & .719 & 2.97 & .723 \\
\hline Community College Visits. & 3.21 & .564 & 3.14 & .616 \\
\hline $\begin{array}{l}\text { A planned, sequential flow of communication to } \\
\text { prospective students, from the beginning to } \\
\text { the end of the recruiting cycle. }\end{array}$ & 3.69 & 1.25 & 3.67 & 1.18 \\
\hline Targeting part-time students. & 2.24 & 1.13 & 2.21 & 1.08 \\
\hline Targeting adult learners. & 2.26 & 1.35 & 2.28 & 1.42 \\
\hline $\begin{array}{l}\text { Asking current students/alumni for applicant } \\
\text { referrals. }\end{array}$ & 2.67 & .815 & 2.78 & .765 \\
\hline Online college fairs. & 1.69 & .433 & 1.72 & .512 \\
\hline Overnight visits for high school students. & 2.03 & .654 & 2.10 & .564 \\
\hline Calling Cell Phones. & 2.38 & 1.41 & 2.38 & 1.37 \\
\hline
\end{tabular}

Scale: 1 = Never, 2 = Rarely, $3=$ Sometimes, $4=$ Often, and $5=$ Always 
Student Retention Strategies. For objectives four and five, the goal was to describe specific student retention strategies utilized by colleges of agriculture for students as well as underrepresented students. The highest-rated student retention strategies for both all and underrepresented students were: (a) academic support, (b) giving students practical work experiences in their intended major, (c) advising by professional staff, one-on-one, (d) programs explicitly designed for first-year students, (e) mandatory first-year experience or orientation course, (f) providing each student with an academic plan/roadmap of classes, (g) mandatory advising by professional staff, one-on-one, (h) early-alert and intervention system for campus-based learners, and (i) faculty development and support in online technology and online teaching pedagogy. In comparison, the lowest-rated retention strategies used with both groups of students were: (a) programs explicitly designed for second-year students, (b) programs for part-time students, (c) programs designed specifically for adult/non-traditional students, and (d) mandatory academic advising for online learning. Table 2 provides an overview of these findings for objectives four and five.

Table 2. Agricultural Student Retention Strategy Comparison

\begin{tabular}{|c|c|c|c|c|}
\hline Retention Practices & $\begin{array}{l}\text { All Students } \\
\qquad M\end{array}$ & SD & $\begin{array}{l}\text { Underrepresented } \\
\text { Students } \\
\quad M\end{array}$ & SD \\
\hline $\begin{array}{l}\text { Honors programs for academically advanced } \\
\text { students. }\end{array}$ & 3.95 & 1.14 & 3.87 & 1.17 \\
\hline $\begin{array}{l}\text { Academic support (e.g., learning center, math lab, } \\
\text { tutoring). }\end{array}$ & 4.13 & .963 & 4.20 & .970 \\
\hline $\begin{array}{l}\text { Giving students practical work experiences in their } \\
\text { intended major (e.g., internships, volunteer } \\
\text { work, experiential learning, service learning). }\end{array}$ & 4.29 & .685 & 4.33 & .640 \\
\hline Advising by professional staff, one-on-one. & 4.49 & .920 & 4.53 & .858 \\
\hline Supplemental instruction. & 3.38 & .913 & 3.44 & .958 \\
\hline $\begin{array}{l}\text { Programs designed specifically for first-year } \\
\text { students (e.g., orientation for first-year students, } \\
\text { a first-year experience program). }\end{array}$ & 4.42 & .994 & 4.45 & .978 \\
\hline $\begin{array}{l}\text { Mandatory first-year experience or orientation } \\
\text { course. }\end{array}$ & 3.95 & 1.50 & 3.98 & 1.48 \\
\hline Discipline Specific Living-Learning Communities. & 3.36 & 1.45 & 3.35 & 1.44 \\
\hline $\begin{array}{l}\text { Providing each student with an academic } \\
\text { plan/roadmap of courses. }\end{array}$ & 4.55 & .789 & 4.56 & .788 \\
\hline $\begin{array}{l}\text { Mandatory advising by professional staff, one-on- } \\
\text { one. }\end{array}$ & 4.20 & 1.07 & 4.24 & 1.03 \\
\hline $\begin{array}{l}\text { Financial literacy programs to assist students and } \\
\text { parents with managing their personal finances. }\end{array}$ & 2.93 & 1.28 & 3.02 & 1.26 \\
\hline $\begin{array}{l}\text { Programs designed specifically for adult/non- } \\
\text { traditional students. }\end{array}$ & 2.15 & 1.04 & 2.11 & 1.03 \\
\hline
\end{tabular}


Online social networking to engage students in online communities.

Programs designed specifically for transfer students.

Remaining in contact with students who are leaving.

Early-alert and intervention system for campusbased learners.

Programs designed specifically for second-year students.

Programs for part-time students.

Programs designed specifically for online learners.

Mandatory training program for online faculty.

Faculty development and support in online technology and online teaching pedagogy.

Mandatory academic advising for Online learning.

Early-alert and intervention system for online learners.

\begin{tabular}{llll}
2.82 & 1.03 & 2.84 & 1.06 \\
3.09 & 1.04 & 3.05 & 1.20 \\
2.82 & .925 & 2.84 & .898 \\
4.00 & 1.13 & 4.02 & 1.14 \\
1.96 & 1.01 & 1.98 & 1.00 \\
1.82 & .819 & 1.85 & .870 \\
2.76 & 1.40 & 2.69 & 1.31 \\
2.85 & 1.38 & 2.85 & 1.38 \\
3.78 & 1.03 & 3.75 & 1.07 \\
2.58 & 1.38 & 2.60 & 1.39 \\
2.93 & 1.41 & 3.00 & 1.38 \\
& & & \\
\hline
\end{tabular}

Scale: $1=$ Never, 2 = Rarely, $3=$ Sometimes, $4=$ Often, and $5=$ Always.

Differences by Agricultural Institution Toe and Diversity Office Presence. Objective six examined if differences existed by agricultural institution type and diversity office presence about the utilization of specific student recruitment and retention strategies. Three null hypotheses were tested:

- $\mathrm{H}_{1}$ : No differences exist among agricultural institution type concerning their decision to utilize specific student recruitment strategies.

- $\mathrm{H}_{2}$ : No differences exist among agricultural institution type concerning their decision to utilize specific student retention strategies.

- $\mathrm{H}_{3}$ : No differences exist among agricultural institutions with college diversity and inclusion offices versus those that do not have diversity and inclusion offices concerning their decision to utilize specific student retention strategies.

For the first hypothesis, statistically significant differences were found regarding community college visits for underrepresented students $(F=3.82, p=.028)$, target adult learners for all students $(F=4.11, p=.022)$, and overnight visits for high school students $(F=3.90, p=.026)$. Specifically, for all three cases, 1862 land-grant institutions indicated a higher use of each recruitment strategy. Therefore, the null hypothesis was rejected (Table 3). 
Table 3. Agricultural College Type Impact (1862, 1890, Non-Land-Grant) Upon Recruitment Strategies

\begin{tabular}{|c|c|c|c|c|c|c|c|c|}
\hline \multirow[t]{2}{*}{ Recruitment Practices } & \multicolumn{4}{|c|}{$\begin{array}{l}\text { All Students } \\
\text { Significance }\end{array}$} & \multicolumn{4}{|c|}{$\begin{array}{c}\text { Underrepresented Students } \\
\text { Significance } \\
\end{array}$} \\
\hline & SS & $d f$ & $F$ & $p$ & SS & $d f$ & $F$ & $p$ \\
\hline Text messaging. & 46.89 & 57 & 1.16 & .320 & 43.37 & 57 & 2.01 & .144 \\
\hline Email. & 36.15 & 57 & .796 & .456 & 45.71 & 57 & .516 & .600 \\
\hline Website optimized for mobile browsers. & 48.91 & 57 & .051 & .950 & 48.91 & 57 & .051 & .950 \\
\hline Campus open house events. & 36.34 & 57 & .770 & .468 & 48.41 & 57 & .217 & .805 \\
\hline $\begin{array}{l}\text { Campus visit days for high school } \\
\text { students. }\end{array}$ & 64.15 & 57 & .411 & .665 & 58.08 & 57 & 1.81 & .172 \\
\hline Weekend visit days. & 78.84 & 57 & .460 & .633 & 83.93 & 57 & .840 & .437 \\
\hline $\begin{array}{l}\text { Booths at State and national FFA and 4- } \\
\text { H conventions. }\end{array}$ & 75.93 & 57 & 1.00 & .373 & 76.84 & 57 & .136 & .873 \\
\hline $\begin{array}{l}\text { Campus Recruiter Visits to High School } \\
\text { Agricultural Education Programs. }\end{array}$ & 89.39 & 57 & .927 & .402 & 79.87 & 57 & .764 & .470 \\
\hline Targeting in-state students. & 50.15 & 57 & .593 & .593 & .334 & 57 & .366 & .695 \\
\hline $\begin{array}{l}\text { Social Media (Facebook, Instagram, } \\
\text { Twitter). }\end{array}$ & 50.98 & 57 & 3.06 & .058 & 51.93 & 57 & 2.58 & .085 \\
\hline $\begin{array}{l}\text { Meetings for Events for High School } \\
\text { Counselors. }\end{array}$ & 82.84 & 57 & 1.24 & .295 & 83.93 & 57 & .951 & .393 \\
\hline Community College Visits. & 73.51 & 57 & 2.68 & .077 & 72.89 & 57 & 3.82 & $.028^{*}$ \\
\hline $\begin{array}{l}\text { A planned, sequential flow of } \\
\text { communication to prospective } \\
\text { students, from the beginning to the } \\
\text { end of the recruiting cycle. }\end{array}$ & 78.41 & 57 & 1.37 & .346 & 82.77 & 57 & 2.06 & .137 \\
\hline Targeting part-time students. & 50.62 & 57 & 2.71 & .075 & 53.51 & 57 & 1.88 & .161 \\
\hline Targeting adult learners. & 47.12 & 57 & 4.11 & $.022 *$ & 51.58 & 57 & 1.86 & .165 \\
\hline $\begin{array}{l}\text { Asking current students/alumni for } \\
\text { applicant referrals. }\end{array}$ & 62.77 & 57 & 1.48 & .236 & 76.08 & 57 & 1.48 & .235 \\
\hline Online college fairs. & 42.41 & 57 & 1.26 & .290 & 47.58 & 57 & 1.33 & .270 \\
\hline $\begin{array}{l}\text { Overnight visits for high school } \\
\text { students. }\end{array}$ & 53.93 & 57 & 3.31 & $.044^{*}$ & 69.37 & 57 & 3.90 & $.026^{*}$ \\
\hline Calling cell phones & 81.65 & 57 & 2.00 & .145 & 87.65 & 57 & 3.15 & .050 \\
\hline
\end{tabular}

Significant: ${ }^{*} \mathrm{p}<.05=$ statistically significant difference 
For hypothesis two, a statistically significant difference was found on whether programs were designed specifically for first-year students $(F=3.74, p=.030)$ with 1862 Land-Grant Institutions exhibiting the highest mean. Therefore, the null hypothesis was rejected (Table 4).

For hypothesis three, no statistically significant differences were found. Therefore, we accepted the null hypothesis because there was no difference existing regarding how institutions handled agricultural student retention based upon whether they have a diversity office in their respective college of agriculture (Table 5).

Table 4. Agricultural College Type Impact (1862, 1890, Non-Land-Grant) Upon Retention Strategies

\begin{tabular}{|c|c|c|c|c|c|c|c|c|}
\hline \multirow[t]{2}{*}{ Retention Practices } & \multicolumn{4}{|c|}{ All Students } & \multicolumn{4}{|c|}{ Underrepresented Students } \\
\hline & SS & $d f$ & $F$ & $p$ & SS & $d f$ & $F$ & $p$ \\
\hline $\begin{array}{l}\text { Honors programs for academically } \\
\text { advanced students. }\end{array}$ & 70.83 & 54 & .121 & .887 & 74.01 & 54 & .003 & .997 \\
\hline $\begin{array}{l}\text { Academic support (e.g., learning center, } \\
\text { math lab, tutoring). }\end{array}$ & 50.10 & 54 & .079 & .924 & 50.80 & 54 & .183 & .834 \\
\hline $\begin{array}{l}\text { Giving students practical work } \\
\text { experiences in their intended major } \\
\text { (e.g., internships, volunteer work, } \\
\text { experiential learning, service } \\
\text { learning). }\end{array}$ & 25.34 & 54 & .453 & .638 & 22.10 & 54 & .193 & .825 \\
\hline $\begin{array}{l}\text { Advising by professional staff, one-on- } \\
\text { one. }\end{array}$ & 45.74 & 54 & .772 & .467 & 39.70 & 54 & .534 & .589 \\
\hline Supplemental instruction. & 44.98 & 54 & .192 & .826 & 49.52 & 54 & . 105 & .900 \\
\hline $\begin{array}{l}\text { Programs designed specifically, for first- } \\
\text { year students (e.g., orientation for } \\
\text { first-year students, a first-year } \\
\text { experience program). }\end{array}$ & 53.38 & 54 & 3.74 & $.030 *$ & 51.63 & 54 & 2.72 & .075 \\
\hline $\begin{array}{l}\text { Mandatory first year experience or } \\
\text { orientation course. }\end{array}$ & 122.83 & 54 & 1.92 & .156 & $\begin{array}{c}118.9 \\
8\end{array}$ & 54 & 1.92 & .156 \\
\hline $\begin{array}{l}\text { Discipline-Specific Living-Learning } \\
\text { Communities. }\end{array}$ & 114.72 & 54 & .868 & .426 & $\begin{array}{c}112.4 \\
3\end{array}$ & 54 & .815 & .448 \\
\hline $\begin{array}{l}\text { Providing each student with an academic } \\
\text { plan/roadmap of courses. }\end{array}$ & 33.63 & 54 & 1.34 & .269 & 33.52 & 54 & 1.49 & .233 \\
\hline $\begin{array}{l}\text { Mandatory advising by professional } \\
\text { staff, one-on-one. }\end{array}$ & 62.80 & 54 & 1.27 & .289 & 57.92 & 54 & 1.72 & .188 \\
\hline $\begin{array}{l}\text { Financial literacy programs to assist } \\
\text { students and parents with managing } \\
\text { their personal finances. }\end{array}$ & 89.70 & 54 & .087 & .917 & 86.65 & 54 & .099 & .906 \\
\hline $\begin{array}{l}\text { Programs designed specifically, for } \\
\text { adult/non-traditional students. }\end{array}$ & 58.86 & 54 & 1.86 & .166 & 57.34 & 54 & 1.46 & .242 \\
\hline
\end{tabular}


Online social networking to engage students in online communities.

Programs designed specifically, for transfer students.

Remaining in contact with students who are leaving.

Early-alert and intervention system for campus based learners.

Programs designed specifically, for second-year students.

Programs for part-time Students.

Programs designed specifically, for online learners.

Mandatory training program for online faculty.

Faculty development and support in online technology and online teaching pedagogy.

Mandatory academic advising for Online learning.

Early-alert and intervention system for online learners.

\begin{tabular}{|c|c|c|c|c|c|c|c|}
\hline 58.18 & 54 & 2.00 & .145 & 61.52 & 54 & 1.99 & .146 \\
\hline 82.54 & 54 & .558 & .576 & 78.83 & 54 & .580 & .580 \\
\hline 46.18 & 54 & .082 & .921 & 43.52 & 54 & .047 & .954 \\
\hline 70.00 & 54 & 1.34 & .270 & 70.98 & 54 & 1.24 & .296 \\
\hline 55.92 & 54 & .515 & .600 & 54.98 & 54 & .602 & .551 \\
\hline 36.18 & 54 & .158 & .854 & 40.36 & 54 & 1.32 & .275 \\
\hline 105.92 & 54 & .918 & .406 & 93.74 & 54 & .519 & .598 \\
\hline 102.83 & 54 & 2.42 & .098 & $\begin{array}{c}102.8 \\
3\end{array}$ & 54 & 2.42 & .098 \\
\hline 57.38 & 54 & .191 & .827 & 61.81 & 54 & .263 & .770 \\
\hline 103.82 & 54 & 1.62 & .208 & $\begin{array}{c}105.2 \\
0\end{array}$ & 54 & 1.99 & .146 \\
\hline 107.70 & 54 & .276 & .760 & $\begin{array}{c}104.0 \\
0\end{array}$ & 54 & .708 & .498 \\
\hline
\end{tabular}

Significant: ${ }^{*} \mathrm{p}<.05=$ statistically significant difference

Table 5. Diversity Office Impact Upon Retention Strategies

\begin{tabular}{|c|c|c|c|c|c|c|c|c|c|c|c|c|}
\hline \multirow[t]{2}{*}{ Retention Practices } & \multicolumn{5}{|c|}{ All Students } & \multicolumn{7}{|c|}{ Underrepresented Students } \\
\hline & & $M$ & $S E$ & $t$ & $p$ & $d$ & & $M$ & $S E$ & $t$ & $p$ & $d$ \\
\hline \multirow{2}{*}{$\begin{array}{l}\text { Honors programs for } \\
\text { academically advanced } \\
\text { students. }\end{array}$} & Yes & 3.71 & 1.31 & -.100 & .318 & .01 & Yes & 3.59 & .333 & -1.16 & .252 & .16 \\
\hline & No & 4.06 & 1.11 & & & & No & 4.00 & .188 & & & \\
\hline \multirow{2}{*}{$\begin{array}{l}\text { Academicsupport (e.g., } \\
\text { learning center,math } \\
\text { lab, tutoring). }\end{array}$} & Yes & 4.12 & 1.05 & -.085 & .932 & .01 & Yes & 4.29 & .254 & .413 & .681 & .05 \\
\hline & No & 4.14 & .974 & & & & No & 4.17 & .166 & & & \\
\hline \multirow[b]{2}{*}{$\begin{array}{l}\text { Giving students practical } \\
\text { work experiences in } \\
\text { their intended major } \\
\text { (e.g., internships, } \\
\text { volunteer work, } \\
\text { experiential learning, } \\
\text { service learning). }\end{array}$} & Yes & 4.29 & .772 & -.241 & .811 & .03 & Yes & 4.41 & .150 & .369 & .714 & .05 \\
\hline & No & 4.34 & .639 & & & & No & 4.34 & .108 & & & \\
\hline \multirow{2}{*}{$\begin{array}{l}\text { Advising by professional } \\
\text { staff, one-on-one. }\end{array}$} & Yes & 4.59 & .870 & .270 & .788 & .03 & Yes & 4.71 & .143 & .761 & .450 & .10 \\
\hline & No & 4.51 & .951 & & & & No & 4.51 & .161 & & & \\
\hline
\end{tabular}




\begin{tabular}{|c|c|c|c|c|c|c|c|c|c|c|c|c|}
\hline \multirow{2}{*}{ Supplemental Instruction. } & Yes & 3.53 & .871 & .580 & .564 & .08 & Yes & 3.53 & .212 & .252 & .802 & .03 \\
\hline & No & 3.37 & .942 & & & & No & 3.46 & .171 & & & \\
\hline \multirow{2}{*}{$\begin{array}{l}\text { Programs designed } \\
\text { specifically for first- } \\
\text { year students (e.g., } \\
\text { orientation for first-year } \\
\text { students, a first-year } \\
\text { experience program). }\end{array}$} & Yes & 4.71 & .588 & 1.41 & .164 & .19 & Yes & 4.71 & .114 & 1.23 & .223 & .17 \\
\hline & No & 4.29 & 1.15 & & & & No & 4.34 & .196 & & & \\
\hline \multirow{2}{*}{$\begin{array}{l}\text { Mandatory first-year } \\
\text { experience or } \\
\text { orientation course. }\end{array}$} & Yes & 4.24 & 1.56 & 1.15 & .253 & .02 & Yes & 4.18 & .386 & .843 & .403 & .11 \\
\hline & No & 3.71 & 1.50 & & & & No & 3.80 & .249 & & & \\
\hline \multirow{2}{*}{$\begin{array}{l}\text { Discipline Specific } \\
\text { Living-Learning } \\
\text { Communities. }\end{array}$} & Yes & 3.82 & 1.01 & 1.59 & .118 & .21 & Yes & 3.82 & .246 & 1.68 & .099 & .03 \\
\hline & No & 3.14 & 1.61 & & & & No & 3.11 & .268 & & & \\
\hline \multirow{2}{*}{$\begin{array}{l}\text { Providing each student } \\
\text { with an academic } \\
\text { plan/roadmap of } \\
\text { courses. }\end{array}$} & Yes & 4.47 & .943 & -.841 & .404 & .11 & Yes & 4.47 & .229 & -.976 & .334 & .04 \\
\hline & No & 4.66 & .639 & & & & No & 4.69 & 107 & & & \\
\hline \multirow{2}{*}{$\begin{array}{l}\text { Mandatory advising by } \\
\text { professional staff, one- } \\
\text { on-one. }\end{array}$} & Yes & 4.47 & .717 & 1.21 & .268 & .16 & Yes & 4.53 & .151 & 1.27 & .208 & .02 \\
\hline & No & 4.11 & 1.20 & & & & No & 4.14 & 197 & & & \\
\hline \multicolumn{13}{|l|}{ Financial literacy } \\
\hline $\begin{array}{l}\text { programs to assist } \\
\text { students and parents }\end{array}$ & $\begin{array}{l}\text { Yes } \\
\text { No }\end{array}$ & & $\begin{array}{l}1.37 \\
1.23\end{array}$ & 1.68 & .098 & .23 & & & $\begin{array}{l}.311 \\
.208\end{array}$ & 1.97 & .054 & .26 \\
\hline $\begin{array}{l}\text { with managing their } \\
\text { personal finances. }\end{array}$ & & & & & & & & & & & & \\
\hline \multirow{2}{*}{$\begin{array}{l}\text { Programs designed } \\
\text { specifically for } \\
\text { adult/non-traditional } \\
\text { students. }\end{array}$} & Yes & 1.94 & .827 & -.996 & .324 & .13 & Yes & 1.94 & .201 & -.823 & .414 & .11 \\
\hline & No & 2.26 & 1.17 & & & & No & 2.20 & 196 & & & \\
\hline \multirow{2}{*}{$\begin{array}{l}\text { Online social networking } \\
\text { to engage students in } \\
\text { online communities. }\end{array}$} & Yes & 3.24 & 1.43 & 1.81 & .076 & .09 & Yes & 3.29 & .254 & 1.96 & .055 & .26 \\
\hline & No & 2.69 & 1.17 & & & & No & 2.69 & .178 & & & \\
\hline \multirow{2}{*}{$\begin{array}{l}\text { Programs designed } \\
\text { specifically for transfer } \\
\text { students. }\end{array}$} & Yes & 3.24 & .985 & .706 & .484 & .09 & Yes & 3.12 & .342 & .399 & .691 & .05 \\
\hline & No & 2.97 & .906 & & & & No & 2.97 & 194 & & & \\
\hline \multirow{2}{*}{$\begin{array}{l}\text { Remaining in contact with } \\
\text { students who are } \\
\text { leaving. }\end{array}$} & Yes & 2.71 & .951 & -.860 & .394 & .12 & Yes & 2.71 & .239 & -.881 & .383 & .12 \\
\hline & No & 2.94 & 1.21 & & & & No & 2.94 & .147 & & & \\
\hline \multirow{2}{*}{$\begin{array}{l}\text { Early-alert and } \\
\text { intervention system for } \\
\text { campus based learners. }\end{array}$} & Yes & 4.18 & .951 & .697 & .489 & .09 & Yes & 4.18 & .231 & .606 & .547 & .07 \\
\hline & No & 3.94 & 1.21 & & & & No & 3.97 & .207 & & & \\
\hline \multirow{2}{*}{$\begin{array}{l}\text { Programs designed } \\
\text { specifically for second- } \\
\text { year students. }\end{array}$} & Yes & 2.06 & 1.14 & .375 & .710 & .05 & Yes & 2.06 & .277 & .285 & .777 & .04 \\
\hline & No & 1.94 & .998 & & & & No & 1.97 & .166 & & & \\
\hline \multirow{2}{*}{$\begin{array}{l}\text { Programs for part-time } \\
\text { students. }\end{array}$} & Yes & 1.76 & .752 & -.262 & .795 & .03 & Yes & 1.82 & .196 & -.129 & .898 & .01 \\
\hline & No & 1.83 & .857 & & & & No & 1.86 & 154 & & & \\
\hline \multirow{2}{*}{$\begin{array}{l}\text { Programs designed } \\
\text { specifically for online }\end{array}$} & Yes & 2.47 & 1.37 & -1.20 & .235 & .16 & Yes & 2.47 & .333 & -.983 & .330 & .13 \\
\hline & No & 2.97 & 1.42 & & & & No & 2.86 & .221 & & & \\
\hline
\end{tabular}


Journal of Research in Technical Careers

\begin{tabular}{|c|c|c|c|c|c|c|c|c|c|c|c|c|}
\hline $\begin{array}{l}\text { Mandatory training } \\
\text { program for online } \\
\text { faculty. }\end{array}$ & $\begin{array}{l}\text { Yes } \\
\text { No }\end{array}$ & $\begin{array}{l}2.41 \\
3.06\end{array}$ & $\begin{array}{l}1.00 \\
1.55\end{array}$ & -1.55 & . 125. & .21 & $\begin{array}{l}\text { Yes } \\
\text { No }\end{array}$ & $\begin{array}{l}2.41 \\
3.06\end{array}$ & $\begin{array}{l}.243 \\
.262\end{array}$ & -1.55 & . 125 & .21 \\
\hline $\begin{array}{l}\text { Faculty development and } \\
\text { support in online } \\
\text { technology and online } \\
\text { teaching pedagogy. }\end{array}$ & $\begin{array}{l}\text { Yes } \\
\text { No }\end{array}$ & $\begin{array}{l}3.65 \\
3.91\end{array}$ & $\begin{array}{l}.996 \\
1.06\end{array}$ & -.865 & .391 & .12 & $\begin{array}{l}\text { Yes } \\
\text { No }\end{array}$ & $\begin{array}{l}3.65 \\
3.86\end{array}$ & $\begin{array}{l}.242 \\
.193\end{array}$ & -.648 & .520 & .09 \\
\hline $\begin{array}{l}\text { Mandatory academic } \\
\text { advising for Online } \\
\text { Learning. }\end{array}$ & $\begin{array}{l}\text { Yes } \\
\text { No }\end{array}$ & $\begin{array}{l}2.47 \\
2.66\end{array}$ & $\begin{array}{l}1.37 \\
1.43\end{array}$ & -.446 & .658 & .06 & $\begin{array}{l}\text { Yes } \\
\text { No }\end{array}$ & $\begin{array}{l}2.53 \\
2.66\end{array}$ & $\begin{array}{l}.344 \\
.242\end{array}$ & -.302 & .764 & .04 \\
\hline $\begin{array}{l}\text { Early-alert and } \\
\text { intervention system for } \\
\text { online learners. }\end{array}$ & $\begin{array}{l}\text { Yes } \\
\text { No }\end{array}$ & $\begin{array}{l}3.12 \\
2.91\end{array}$ & $\begin{array}{l}1.49 \\
1.40\end{array}$ & .480 & .633 & .06 & $\begin{array}{l}\text { Yes } \\
\text { No }\end{array}$ & $\begin{array}{l}3.12 \\
2.97\end{array}$ & $\begin{array}{l}.393 \\
.230\end{array}$ & .352 & .726 & .10 \\
\hline
\end{tabular}

The Impact of College of Agriculture Diversity Offices upon Retention Practices

Scale: $1=$ Never, 2 = Rarely, $3=$ Sometimes, $4=$ Often, and $5=$ Always Significant

${ }^{*} \mathrm{p}<.05$ = statistically significant difference

\section{Conclusions, Recommendations, and Implications}

This national study intended to describe the student recruitment and retention strategies utilized by colleges of agriculture in the United States. It is important to note that this study was unique in several ways. First, it provided a broadened scope beyond the survey of 1862 land-grant institutions by also investigating 1890 land-grant and non-landgrant institutions, both of which are under-researched in the existing agricultural recruitment and retention literature. As a result, the current study provided a more granular view of the higher education landscape for colleges of agriculture.

In this study, the respondents reported the majority of their student enrollments at their institutions were White, with Black, Hispanic, Asian, and other groups comprising a minority of their student populations. Similarly, respondents also indicated that faculty were primarily White in their colleges of agriculture. Through our analysis of sub-group percentages, however, we found that the ethnic makeup reported in this investigation of faculty in colleges of agriculture were not reflective of the general population in the United States. With current predictions that the world's population will explode to more than 10 billion people by 2050, additional demands will be placed on the environment. To feed and sustain our growing communities, we recommend that faculty representation across all racial and ethnic sectors be present within colleges of agriculture in the future (United Nations, 2015).

Another key finding of this investigation was that most reporting institutions revealed they did not have an office of diversity in the college. Given the increasing diversity of the United States population and higher education in general, we recommend that colleges of agriculture consider establishing an office of diversity and inclusion to address the needs of underrepresented populations better. Williams, Berger, and McClendon (2005) indicated that emphasizing inclusion in academic units impacts student retention, especially for students who represent at-risk populations. Therefore, 
implementing such a change could improve the overall educational climate and, perhaps, strengthen the agricultural workforce moving forward.

The highest-rated strategies related to using digital-based mechanisms such as email communication, websites optimized for mobile browsers, social media, and sequential flow of digital communication during the entire recruitment cycle. Such findings support Ruffalo Noel Levitz's (2017) findings. However, although digitally-based strategies were highly valued, traditional approaches such as campus visit days for high school students and campus open house events were also ranked highly by respondents, which supports findings reported by Ruffalo Noel Levitz as well. It is noted that respondents reported that all strategies were used to recruit both racial majority and underrepresented student populations. These strategies appear to support the needs of Generation Z, which has begun to take over the traditional undergraduate enrollment nationally. Generally, Generation Z prefers digital communication as well as face-to-face interactions (Patel, 2017).

Conversely, recruitment strategies such as cell phone communication, targeting part-time students, and events for high school counselors were ranked lower by the college of agriculture academic administrators. These findings conflict with those reported by Ruffalo Noel Levitz (2017) who suggested such practices were effective. Perhaps, these practices have not been as effective in the context of agriculture, or maybe are outdated considering changing student demographics.

Regarding student retention, within this study the highest-rated strategies by respondents were academic support, providing work experiences in the significant, programs and courses for first-year students, early-alert systems for campus-based students, mandatory advisement by professionals, and faculty training in online pedagogy. These findings support the retention strategies reported by Ruffalo Noel Levitz (2017). In contrast, the lowest-rated retention strategies wihin in this study were techniques such as programs designed specifically for second-year students, applications for part-time students, programs designed specifically for adult or non-traditional students, and mandatory academic advising for online learning. These findings are thought-provoking, considering the number of adult and part-time students that comprise higher education enrollment today, the increasing presence of online education, and the need to increase student-centered experiences for learners throughout their undergraduate experience. As such, the authors recommend that colleges of agriculture adopt a holistic approach to student retention and implement practices that best fit their mission and student profiles (Thammasiri et al., 2013), while also considering national trends regarding best practices for student retention.

When examining whether differences existed between the types of agricultural institutions regarding student recruitment, we found that administrators from 1862 landgrant institutions reported using specific strategies more than other institutional types. For example, statistically significant differences $(p<.05)$ existed between 1862 land-grant institutions and others institutional types for the following recruitment strategies: (a) community college visits for underrepresented students, (b) targeting adult learners, and (c) overnight visits with high school students. However, the remaining sixteen recruitment strategies examined did not demonstrate statistically significant $(p>.05)$ differences. 
Consequently, we conclude that colleges of agriculture, regardless of institutional type, are generally utilizing similar student recruitment strategies, with 1862 land-grants placing an emphasis on recruiting underrepresented populations.

When testing differences in institutional type concerning student retention strategies, only one statistically significant difference $(p<.05)$ was identified. In particular, 1862 land-grant institutions reported using programs designed for first-year students more than other institutional types. Programs for first-year students are a crucial strategy for improving student retention and ultimately graduation rates (Dunn et al., 2009) because the students who are engaged with the university early often establish a more authentic connection. With this in mind, we recommend that colleges of agriculture at non-land-grant and 1890 land-grant institutions examine how they engage first-year students. Perhaps, providing programming for first-year students could positively affect student retention at these institutions in the future. Outside of this strategy, it was found that of the other 22 student retention strategies tested, no statistically significant $(p<.05)$ differences were found. Thus, we conclude that most colleges of agriculture are using similar strategies for student retention. This finding was true for plans regarding racial majority students as well as those from underrepresented populations.

Finally, we assessed whether the presence of an office of diversity and inclusion influenced the retention strategies of colleges of agriculture and found no statistically significant $(p>.05)$ differences. This finding was surprising, particularly regarding the influence of the Office of Diversity and Inclusion in helping to retain underrepresented student populations. Given the issues that have been historically encountered by underrepresented students within agricultural colleges (Westbrook \& Alston, 2007), offices of diversity and inclusion were established to address problems of retention with these student populations directly. This finding conflicts with those reported by Williams, Berger, and McClendon (2005), who suggested that inclusion of an office of diversity and inclusion in academic units could positively influence student retention and degree completion for at-risk student populations. Therefore, the researchers recommend that colleges of agriculture reexamine the mission and activities of their offices of diversity and inclusion. Perhaps, through a realignment of the goals and values, offices of diversity could serve the underrepresented student population more efficiently in the future. Given that the agricultural industry continues to have a challenging time with filling positions with qualified agricultural workers (Goecker et al., 2015), improving underrepresented agricultural student retention is critically important. Also, perhaps, offices of diversity and inclusion could better enact positive change moving forward.

\section{Agricultural Student Retention Model}

In this investigation, we highlighted several strategies used by colleges of agriculture in the United States regarding student recruitment and retention. As a result, we provided a deeper understanding of key differences among institutional types concerning how they approach student recruitment and retention. We now have a complete understanding of how to design and deliver tailored recruitment and retention campaigns based on the unique context of an institution. With the reality of increasing student loan 


\section{Agricultural Student Retention Model}

\begin{tabular}{|l|}
\hline \multicolumn{1}{|c|}{ ADVISING RELATED STRATIGIES } \\
1. Mandatory advising by professional staff, one- \\
on-one \\
2. Advising by professional staff, one-on-one \\
3. Providing each student with an academic \\
plan/roadmap of courses \\
4. Early-alert and intervention system for campus \\
based learners \\
5. Faculty development and support in online \\
technology and online teaching pedagogy
\end{tabular}

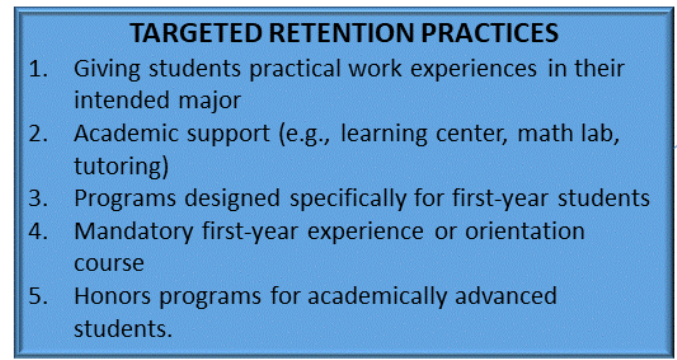

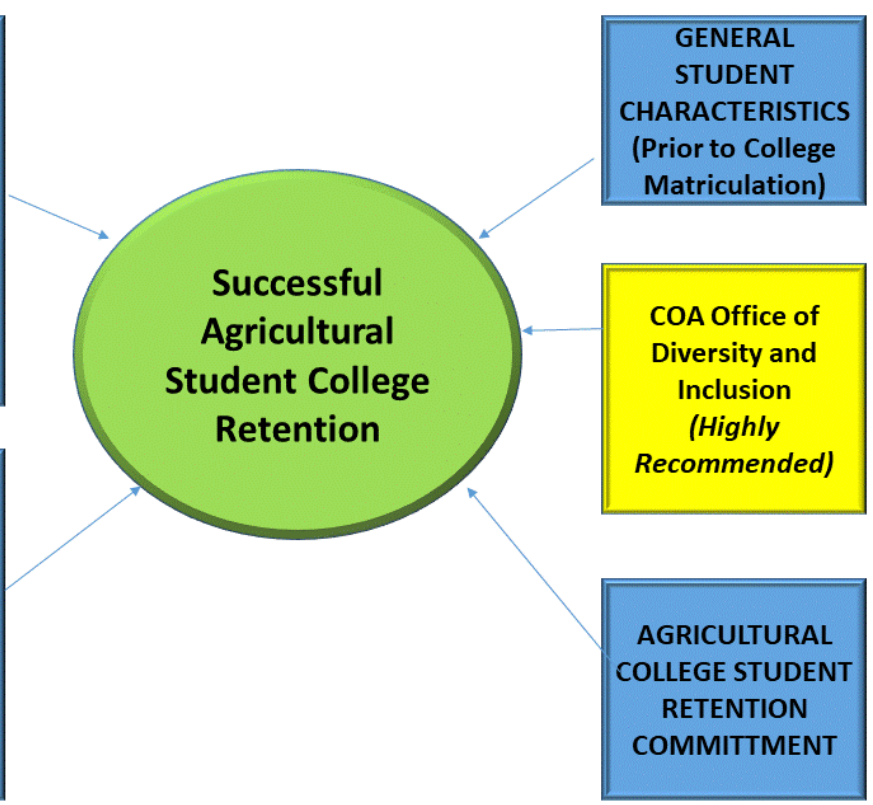

Figure 3. Agricultural Student Retention Model (ASRM).

debt and calls for improved accountability, colleges of agriculture could place more emphasis on improving student graduation rates. As such, the authors developed the agricultural student retention model (ASRM) to help guide colleges of agriculture in enhancing their holistic retention strategies (Figure 3).

The model visually represents the distinct but intersecting factors that impact agricultural student retention strategies. For example, the factors identified in this study highlighted the importance of improved advising and targeted retention practices. Additionally, when designing this model, the researchers emphasized student characteristics and prior college matriculation and student retention commitment factors such as the inclusion of an office of diversity and inclusion (Astin, 1985; Bobbitt, 2006; Garton et al., 2001; Hansen, Ward, Khosla, Fenwick, \& Moore, 2007; Pope \& Fermin, 2003; Robinson, Garton, \& Washburn, 2007; Rocca \& Washburn, 2007; Shrestha, 2009; Shrestha, 2011; Sivapirunthep, 2000; Washburn, Garton, \& Vaughn, 2002; Westbrook \& Alston, 2007; Lynch, 2001; Dyer, Breja, \& Anderson, 1999). The authors recommend that colleges of agriculture consider using the ASRM as a tool to increase student retention as they navigate their unique institutional context. As a result of using this model, perhaps more considerable progress can be made toward creating a sustainable agricultural workforce that is also more reflective of U.S. population demographics. 


\section{References}

Adams-Johnson, S., Cranmore, J., Holloway, A. M. J. \& Wiley, J. D. (2019). Higher education recruitment in the United States: A chronology of significant literature. Journal of Educational Administration and History, 51(3), 213-238. https://doi.org/10.1080/00220620.2018.1539704

Allen, J., Robbins, S. B., Casillas, A., \& Oh, I. S. (2008). Third-year college retention and transfer: Effects of academic performance, motivation, and social connectedness. Research in Higher Education, 49(7), 647-664. https://doi.org/10.1007/s11162-008-9098-3

Astin, A. W. (1985). Achieving educational excellence. San Francisco, CA: Jossey-Bass.

Baker, L. M., Settle, Q., Chiarelli, C., \& Irani, T. (2013). Recruiting strategically: Increasing enrollment in academic programs of agriculture. Journal of Agricultural Education, 54(3), 54. https://doi.org/10.5032/jae.2013.03054

Beale, A. V. (2012). The more things change, the more they stay the same. Journal of College Admission 21(4), 1-21.

Bobbitt, R. K. (2006). Factors influencing recruitment, retention, and job placement in the College of Agricultural Sciences and Natural Resources at Texas Tech University (Master's thesis). Retrieved from ProQuest (57643).

Bradburn, E. M., Nevill, S. \& Cataldi, E. F. (2006). Where are they now? A description of 19921993 bachelor's degree recipients 10 years later. Washington, DC: Institute of Educational Sciences. National Center for Educational Statistics.

Brown, F. G. (1983). Principles of educational and psychological testing (3rd ed). New York: Holt, Rinehart and Winston.

Bruffaerts, R., Mortier, P., Kiekens, G., Auerbach, R. P., Cuijpers, P., Demyttenaere, K., ... \& Kessler, R. C. (2018). Mental health problems in college freshmen: Prevalence and academic functioning. Journal of Affective Disorders, 225(1), 97-103.

Cantor, N. (2004). Civic engagement: The university as a public good. Liberal Education, 90(2), 18-25.

Chapman, D. W. (1981). A model of student college choice. The Journal of Higher Education, 52(5), 490-505. https://doi.org/10.1080/00221546.1981.11778120

Day, J.C., Newburger, E.C. (2002). The big payoff: Educational attainment and synthetic estimates of work-life earnings. Washington, DC: Economics and Statistics Administration, U.S. Department of Commerce

Dillman, D. A., Smyth, J. D., \& Christian, L. M. (2014). Internet, phone, mail, and mixed-mode surveys: The tailored design method (4th ed.). Hoboken, NJ: John Wiley \& Sons.

Dunn, J. R., Hains, B. J., \& Epps. R. B. (2013). Stakeholder's perspectives: Students' perceptions of retention efforts in a college of agriculture. NACTA Journal, 57(1), 2-9.

Dyer, J. E., Breja, L. M., \& Anderson, R. J. (1999). Attitudes of college of agriculture freshmen toward agriculture. Journal of Agricultural Education 40(2), 1-10.

Dyer, J. E., Breja, L. M., \& Wittler, P. S. H. (2002). Predictors of student retention in colleges of agriculture. Paper presented at the 27th Annual National Agricultural Education Research Conference, San Diego, CA.

Fan, W., \& Yan, Z. (2010). Factors affecting response rates of the web survey: A systematic review. Computers in Human Behavior, 26(2), 132-139.

Field, A. (2013). Discovering statistics using IBM SPSS statistics (4th ed.). Thousand Oaks, CA: Sage.

Friedman, Z. (2019). Student loan debt statistics in 2019: A \$1.5 trillion crisis. Forbes. Retrieved 
from https://www.forbes.com/sites/zackfriedman/2019/02/25/student-loan-debt-statistics2019/\#76461353133f

Garton, B. L., Dyer, J. E., King, B. O. (2001). Factors associated with the academic performance and retention of college agriculture students. NACTA Journal, 45(1), 21-27.

Goecker, A. D., Smith, E., Marcos Fernandez, J., Ali, R., \& Goetz, R. (2015). Employment opportunities for college graduates in food, renewable energy, and the environment: United States, 2015-2020. Retrieved from http://www.ag.purdue.edu/USDA/employment/Documents/ USDAEmployOp2010.pdf

Hansen, N., S., Ward, R., Khosla, A., Fenwick, R., \& Moore, B. (2007). What does undergraduate enrollment in soil and crop sciences mean for the future of agronomy? Agronomy Journal, 99(4), 1169-1174.

Johnson, D. M., Shoulders, C. W., Edgar, L. D., \& Dixon, B. L. (2018). Predictors of freshman to sophomore retention in a College of Agricultural, Food and Life Sciences. NACTA Journal, 62(3), 218-224. Retrieved from https://www.nactateachers.org/index.php/volume-62-number-3-september-2018/2774freshman-to-sophomore-retention

Koon, L. A. F., Frick, M. J., \& Igo, C. G. (2009). What kind of students are enrolling in a college of agriculture and are they staying? A mixed methods approach. NACTA Journal, 53(2), 21-28. Retrieved from https://www.nactateachers.org/attachments/article/159/Koon_June_2009_NACTA_JOU NAL_final-4.pdf

Kretovics, M. A. (2011). Business practices in higher education: A guide for today's administrators. New York, NY: Routledge.

Lance, C. E., Butts, M. M., \& Michels, L. C. (2006). The Sources of Four Commonly Reported Cutoff Criteria. What Did They Really Say? Organizational Research Methods, 9, 202220. http://dx.doi.org/10.1177/1094428105284919

Lindner, J. R, Murphy, T. H, \& Briers, G. E. (2001). Handling nonresponse in social science research. Journal of Agricultural Education, 42(4), 43-53.

https://doi.org/10.5032/jae.2001.04043

Lindner, J. R., \& Wingenbach, G. J. (2002). Communicating the handling of nonresponse error in journal of extension research in brief articles. Journal of Extension, 40(6), 1-6.

Lynch, T. L. (2001). Factors influencing the enrollment of minority students in agricultural science programs at Virginia Tech (Doctoral dissertation). Retrieved from ProQuest (3006097).

Mattern, K., Radunzel, J., \& Westrick, P. (2015). Development of STEM readiness benchmarks to assist educational and career decision making. Retrieved from http://files.eric.ed.gov/fulltext/ED558031.pdf

Miller, L. E., \& Smith, K. L. (1983). Handling non-response issues. Journal of Extension, 21(5), 45-50.

National Research Council. (2009). Transforming agricultural education for a changing world. Washington, DC: The National Academies Press.

Nunnally, J. C. (1967). Psychometric theory. New York, NY: McGraw Hill Book Co. Inc. Nunnally, J. C. (1978). Psychometric theory (2nd ed.). New York, NY: McGraw-Hill.

Patel, D. (2017, September 21). Eight ways Generation Z will differ from millennials in the workplace. Forbes. Retrieved from: https://www.forbes.com/sites/deeppatel/2017/09/21/8-ways-generation-z-will-differfrom-millennials-in-the-workplace/\#56bb132976e5 
Pervin, L. A., Reik, L. E., \& Dalrymple, W. (2015). The college dropout and the utilization of talent (Vol. 2058). Princeton University Press.

Pope, M. L. \& Fermin, B. (2003). The perceptions of college students regarding the factors most influential in their decision to attend postsecondary education. College \& University Journal, 78(4), 19-25.

Rayfield, J., Murphrey, T. P., Skaggs, C., \& Shafer, J. (2013) Factors that influence student decisions to enroll in a college of agriculture and life sciences. NACTA Journal, 57(1), 88-93.

Robinson, J. S., Garton, B. L., \& Washburn, S. G. (2007). The influential factors that first-time enrollees utilize when choosing a college of agriculture. NACTA Journal 51(2), 27-33.

Rocca, S. J. (2013). Comparison of factors influencing the college choice of matriculant and nonmatriculant students into a college of agriculture. NACTA Journal, 57(2), 72-78.

Rocca, S. J., \& Washburn, S. G. (2005). Factors influencing the college choices of high school and transfer matriculants into a college of agriculture. NACTA Journal, 49(1), 32-38.

Rocca, S. J., \& Washburn. S. G. (2007). Comparison of factors influencing the college choice of FFA and Non-FFA members into a college of agriculture. Paper presented at the 2007 American Association for Research Conference, Minneapolis, MN.

Ruffalo Noel Levitz. (2015). Higher Ed Benchmarks: Trends in enrollment management - 2015 student retention and college completion practices benchmark report for two-year and fouryear institutions.

Ruffalo Noel Levitz. (2017). Higher Ed Benchmarks: 2017 marketing and student recruitment report of effective practices.

Schmidt, F. L., \& Hunter, J. E. (1996). Measurement error in psychological research: Lessons from 26 research scenarios. Psychological Methods, 1(2), 199-223.

Shrestha, K. M. (2009). Students' perspectives on undergraduate education in the College of Agriculture and Natural Resources at Michigan State University (Doctoral dissertation). Retrieved from ProQuest (48823).

Shrestha, K. M., Suvedi, M., \& Foster, E. F. (2011). Who enrolls in agriculture and natural resources majors: A case from Michigan State University. NACTA Journal, 55(3), 33.

Sivapirunthep, P. (2000). A study of selected characteristics and attitudes toward agriculture of undergraduate agriculture majors at Mississippi State University. Retrieved from ProQuest (9970339).

Stair, K., Danjean, S., Blackburn, J. J., \& Bunch, J. C. (2016). A major decision: Identifying factors that influence agriculture students' choice of academic major. Journal of Human Sciences and Extension, 4(2), 111-125.

STEM Food and Ag Council. (2014). Annual report. https://www.agripulse.com/ext/resources/pdfs/s/t/e/r/t/STEM_Food_Ag_Council_Report. pdf. July 14, 2017.

Thammasiri, D., Delen, D. Meesad, P., \& Kasap. N. (2013). A critical assessment of imbalanced class distribution problem: The case of predicting freshmen student attrition. Expert Systems with Application, 41(2), 321-330. https://10.1016/j.eswa.2013.07.046.

Washburn, S. G., Garton, B. L., \& Vaughn, P. R. (2002). Factors influencing college choice of agriculture students college-wide compared with students majoring in agricultural education. Paper presented at the 24th National Agricultural Education Research Conference, Las Vegas, NV.

Westbrook, J. R., \& Alston, A. J. (2007). Recruitment and retention strategies utilized by 1890 land grant institutions in relation to African American students. Journal of Agricultural Education, 48(3), 123-134. 
Williams, D. A., Berger, J. B., \& McClendon, S. A. (2005). Toward a model of inclusive excellence and change in postsecondary institutions. Washington, DC: American Association of Colleges and Universities.

United Nations. (2015). World population prospects: The 2015 revision, (Data Booklet. ST/ESA/SER.A377). Retrieved from http://esa.un.org/unpd/wpp/Publications/Files/WPP2015_DataBooklet.pdf 